\title{
Home Maintenance Business Centre Using Global Positioning System (GPS) Technique in IR 4.0 Era
}

\author{
${ }^{1}$ Yousef A.Baker El-Ebiary, ${ }^{2}$ Ainin Sofiya Binti Zaidi , ${ }^{3}$ Syarilla Iryani A. Saany, ${ }^{4}$ Julaily Aida Jusoh, \\ ${ }^{5}$ Hasni Binti Hassan, ${ }^{6}$ M. Hafiz Yusoff, ${ }^{7}$ Ahmad Nazari Mohd Rose
}

${ }^{1}$ Assoc. Prof. Ts. Dr., Faculty of Informatics and Computing, UniSZA University, Malaysia,

${ }^{2}$ Student, Faculty of Informatics and Computing, UniSZA, Malaysia.

${ }^{3}$ Assoc. Prof. Dr., Faculty of Informatics and Computing, UniSZA, Malaysia,

${ }^{4}$ Dr., Faculty of Informatics and Computing, UniSZA, Malaysia,

${ }^{5}$ Dr., Faculty of Informatics and Computing, UniSZA, Malaysia,

${ }^{6}$ Prof. Dato' Dr., Registrar, Albukhary International University, Malaysia,

${ }^{7}$ Assoc. Prof. Dr. Dean, Faculty of Informatics and Computing, UniSZA University, Malaysia,

1yousefelebiary@unisza.edu.my, ${ }^{3}$ syarilla@unisza.edu.my, ${ }^{4}$ julaily@unisza.edu.my , ${ }^{5}$ hasni@unisza.edu.my,

6hafiz.yusoff@aiu.edu.my,7anm@unisza.edu.my

\begin{abstract}
Home helper is very much sought nowadays as it will alleviate the burden of performing the daily chores at home. Home helpers are usually self-employed and provide home service on a part-time basis. However, to acquire home helper services within local community is quite challenging because the public do not know where and how to reach the person with this services. The examples of services that can be offered include chaperone services, garden maintenance, meals preparation, pet care assistance, household chores assistance or even companionship for the elderly. Obviously, there is a gap between home service providers and the local community who demanded the services. People who offer the services usually promote their services using flyers or by passing their phone number to people. This is not a systematic marketing strategy since the dissemination of information is limited to just a small group of local community. Hence, i-HomeHelper acts as a dynamic platform for individuals to promote their services to the nearby public who require their services using modern technologies in Industry Revolution 4.0 (IR4.0) and Global Positioning Systems (GPS). i-HomeHelper enables systematic booking process for the required services and also serves as a platform to promote various services that are available. Details of services that include prices, name of the home helpers and contact numbers are also displayed at the promoting page so that the public can choose the services that meet their criteria. It is anticipated that this application will create an ecosystem of inclusive economic growth for these self-employed individuals and benefits the public who really need an assistance on the household chores or home maintenance
\end{abstract}

Keywords

Dynamic Platform, Website, IR 4.0, GPS, Technology Solutions

Article Received: 10 August 2020, Revised: 25 October 2020, Accepted: 18 November 2020

\section{Introduction}

Nowadays, everything involves technology as we are in the $4^{\text {th }}$ industrial revolution. But still, it is not easy to find a person nearby who can give extra hands in doing the household chores or home maintenance. Juggling between office works and household chores have become an issue especially to working persons. They need a home assistance or home helper but usually they do not know where and how to acquire this service. House helpers operate differently from maids as they do not stay with their employers. House helpers are persons who offer flexible services related to household chores to anyone upon agreement to acquire their services. In other words, home helper is usually selfemployed and provides a part-time service on daily home activities. Examples of services that can be offered include chaperone service, garden maintenance, meals preparation, pet care assistance, household chores assistance or even companionship for the elderly.

These days, people are using social media and other types of digital advertisement platforms to promote their products or services. However, not all people have the access, opportunity or knowledge on digital advertising and promotions [1]. Apart from that, employment is another serious issue especially during the pandemic of Covid-19. Some individuals grab the opportunity to find a job for a living by offering home maintenance skills [2]. However, these services need to be advertised. Normally they are still using ineffective methods to promote their services such using flyers, posters or passing their phone numbers to people. This is not a systematic marketing as it only captures a small niche of the market [3]. Promotions via any social media applications are still not enough to make all nearby potential customers aware of the services offered [4]. Hence, i-HomeHelper acts as a dynamic platform for individuals to promote their services to the nearby public who require their services using modern technologies in Industry Revolution 4.0 (IR4.0) and Global Positioning Systems (GPS). iHomeHelper creates a systematic booking and promoting environment as it only focuses on the home services. Details of the services which include prices, name of the home helpers and contact number are also displayed at the promoting page so that the public can choose the services that meet their needs, budget and closest to their locations [5]. It is anticipated that this application will create an ecosystem of inclusive economic growth for these self- 
employed individuals and benefits the public who really need an assistance on the house chores or home maintenance The remaining of this paper is presented as follows. Section 2 discusses previous work on existing applications similar to this study. In section 3, the methodology and the system framework are discussed followed by section 4 where implementation of this application is presented. Section 5 sums up the study with conclusions and future works.

\section{Literature Review}

Table 1 presents the comparison of existing applications that are similar to i-HomeHelper.

Table 1: Comparisons on Existing Applications

\begin{tabular}{|c|c|c|c|c|}
\hline $\begin{array}{l}\text { Applicati } \\
\text { on }\end{array}$ & $\begin{array}{l}\text { Advanta } \\
\text { ge }\end{array}$ & Platform & $\begin{array}{l}\text { Disadvanta } \\
\text { ge }\end{array}$ & $\begin{array}{l}\text { Improvem } \\
\text { ent }\end{array}$ \\
\hline $\begin{array}{l}\text { Maideasy } \\
{[6]}\end{array}$ & $\begin{array}{l}\text { home } \\
\text { cleaning, } \\
\text { moving } \\
\text { in /out } \\
\text { cleaning } \\
\text { and } \\
\text { spring } \\
\text { cleaning. }\end{array}$ & $\begin{array}{l}\text { Mobile } \\
\text { Applicati } \\
\text { on }\end{array}$ & $\begin{array}{l}\text { There is } \\
\text { always a } \\
\text { problem for } \\
\text { the } \\
\text { application. } \\
\text { Users } \\
\text { always find } \\
\text { that the } \\
\text { system is } \\
\text { crashing } \\
\text { while using } \\
\text { the apps. } \\
\text { The } \\
\text { coverage of } \\
\text { the } \\
\text { application } \\
\text { is limited. }\end{array}$ & $\begin{array}{l}\text { Notify } \\
\text { users in } \\
\text { advanced } \\
\text { when the } \\
\text { system will } \\
\text { be updated. }\end{array}$ \\
\hline $\begin{array}{l}\text { SendHelp } \\
\text { er [7] }\end{array}$ & $\begin{array}{l}\text { The } \\
\text { customer } \\
\text { support } \\
\text { is } \\
\text { prompt } \\
\text { and very } \\
\text { helpful. } \\
\text { Services } \\
\text { provided } \\
\text { in the } \\
\text { applicati } \\
\text { on are } \\
\text { variable. }\end{array}$ & $\begin{array}{l}\text { Mobile } \\
\text { Applicati } \\
\text { on }\end{array}$ & $\begin{array}{l}\text { Users need } \\
\text { to register } \\
\text { before } \\
\text { exploring } \\
\text { the } \\
\text { application } \\
\text { in detail. } \\
\text { User } \\
\text { interface is } \\
\text { not fr } \\
\text { while } \\
\text { worker's } \\
\text { details are } \\
\text { not visible } \\
\text { in the } \\
\text { application. } \\
\text { Only a } \\
\text { Singaporean } \\
\text { users can } \\
\text { register to } \\
\text { use the } \\
\text { application. }\end{array}$ & $\begin{array}{l}\text { Users can } \\
\text { explore the } \\
\text { application } \\
\text { before } \\
\text { registration } \\
\text { application } \\
\text { needs to } \\
\text { show } \\
\text { worker } \\
\text { details } \\
\text { r fo } \\
\text { employers' } \\
\text { view. } \\
\text { Admin } \\
\text { need to } \\
\text { monitor the } \\
\text { worker's } \\
\text { performanc } \\
\text { e and take } \\
\text { action if } \\
\text { something } \\
\text { untoward } \\
\text { happens. }\end{array}$ \\
\hline
\end{tabular}

\begin{tabular}{|c|c|c|c|c|}
\hline $\begin{array}{l}\text { UrbanCla } \\
\mathrm{p} \\
\text { Beauty \& } \\
\text { Home } \\
\text { Service } \\
{[8]}\end{array}$ & $\begin{array}{l}\text { A } \\
\text { variety } \\
\text { of } \\
\text { services } \\
\text { for the } \\
\text { suer to } \\
\text { choose } \\
\text { from. } \\
\text { The user } \\
\text { interface } \\
\text { is } \\
\text { friendly } \\
\text { and easy } \\
\text { to use. }\end{array}$ & $\begin{array}{l}\text { Both on } \\
\text { Web- } \\
\text { Based } \\
\text { and } \\
\text { Mobile } \\
\text { Applicati } \\
\text { on. }\end{array}$ & $\begin{array}{l}\text { This system } \\
\text { is only } \\
\text { available in } \\
\text { India. There } \\
\text { is no } \\
\text { chat team } \\
\text { or } \\
\text { customer } \\
\text { care in } \\
\text { this system. } \\
\text { Moreover, } \\
\text { users need } \\
\text { to pay full } \\
\text { fees during } \\
\text { booking } \\
\text { services } \\
\text { sessions. }\end{array}$ & $\begin{array}{l}\text { Adding } \\
\text { functions } \\
\text { of } \\
\text { customer } \\
\text { care and } \\
\text { chat team } \\
\text { would be } \\
\text { better to } \\
\text { help users } \\
\text { to use the } \\
\text { system. }\end{array}$ \\
\hline $\begin{array}{l}\text { Helpers } \\
\text { Near Me } \\
{[9]}\end{array}$ & $\begin{array}{l}\text { This } \\
\text { applicati } \\
\text { on } \\
\text { is easy, } \\
\text { convenie } \\
\mathrm{nt} \text { and } \\
\text { organize } \\
\text { d. } \\
\text { Employe } \\
\text { rs can } \\
\text { make } \\
\text { more } \\
\text { than one } \\
\text { service } \\
\text { at } \\
\text { one time. }\end{array}$ & $\begin{array}{l}\text { Both on } \\
\text { Web } \\
\text { Based } \\
\text { and } \\
\text { Mobile } \\
\text { Applicati } \\
\text { on. }\end{array}$ & $\begin{array}{l}\text { Users need } \\
\text { to pay full } \\
\text { wages for } \\
\text { the service } \\
\text { they have } \\
\text { chosen. } \\
\text { Problems } \\
\text { arise in the } \\
\text { worker } \\
\text { community } \\
\text { as some of } \\
\text { them were } \\
\text { not hired. }\end{array}$ & $\begin{array}{l}\text { Employers } \\
\text { need to pay } \\
\text { a deposit } \\
\text { before they } \\
\text { get their } \\
\text { services. } \\
\text { Limit the } \\
\text { registration } \\
\text { for workers } \\
\text { and } \\
\text { monitor } \\
\text { worker's } \\
\text { performanc } \\
\text { e. } \\
\text { Filter the } \\
\text { worker } \\
\text { based on } \\
\text { their } \\
\text { performanc } \\
\text { e. }\end{array}$ \\
\hline
\end{tabular}

As mentioned earlier, this study embeds GPS in the proposed solution. The Global Positioning System depends on triangulation, which is a strategy for deciding area by estimating distances to focuses at known directions [10]. At any rate, triangulation requires three territories to three known focuses [11]. Then again, finding a Global Positioning System (GPS) point requires four "pseudo" to four satellites. Pseudoranges is the time at which the sign is sent from the satellite encoded on the sign, utilizing the time as indicated by the nuclear clock on board the satellite. The hour of sign gathering is recorded by the recipient utilizing a nuclear clock.

\section{Methodology}

Framework plan and displaying is an organized methodology needed for an intelligible and well-working framework. A base up or top-down methodology is needed to consider all pertinent factors of the framework [12]. In this examination, displaying language is utilized to communicate data and information in a framework's design. They are characterized by a reliable arrangement of rules 
and definitions. Plans are characterized utilizing a setting outline, entity relationship diagram and data dictionary [13]. In this paper, the framework design of i-HomeHelper is depicted as in Figure 2. Figure 2 shows the flows on how the administrator (will be called as admin in future reference), home helpers, and customers interact with the system. The system hosts on a web server, which will be configured to compile on command [14]. It will contain a database, which stores all data and is accessible by the users based on the granted view levels of the users. Users need to login into the system to enable them to access and utilize the application.



Figure 2: Framework Design

i-HomeHelper system uses geolocation Application Programming Interface (API) which will find the nearby service of the required home maintenance as being promoted via i-HomeHelper. In the next section, the implementation of i-HomeHelper will be explained.

\section{i-HomeHelper Implementation}

i-HomeHelper's interface has been built using Html website template and SB Admin. As for work flow development PHP (Hypertext Pre-processor) language has been used to build the system. PHP is widely used because it is an open source for general purpose scripting language, can be embedded into HTML and it is suitable for Web development. This system used HTML5, PHP and JavaScript for the validation. Validation is vital to ensure users to have a minimum chance to make mistakes when operating the system. Open Source database is also used in this system and the database is $43 \mathrm{MySQL}$ version 5.6.26 MySQL Community Server (GPL). Apache version is 2.4.16 was used to run local host servers while Visual studio was used for writing and editing the code.

The testing of i-HomeHelper was done on the techniques black box testing and white box testing to inspect its functionalities. Black box testing module involved login, manage local community user and manage home helpers while the white box testing involved matches and arranges the booking from local community users. Test cases were developed to identify problems that may occur either in the requirement or design of i-HomeHelper. These included specific variables or conditions to compare expected and actual results to determine whether $\mathrm{i}$-HomeHelper is functioning as intended.

Here, i-HomeHelper is a dynamic platform that connects with local community who can gives an extra hand on household chores and home maintenance. i-HomeHelper matches the requirements from people looking for help with helpers seeking flexible and/or part-time work. It equipped with an easy feature for service arrangement on an ad hoc, short term or regular basis. It sets the availability, charges rate and type of services provided which can be viewed on the profile of participated home-helpers. Few screenshots of i-HomeHelper main processes are presented in this paper. As in Figure 2, it is the screenshots on the local community profile who want to acquire services via i-HomeHelper platform application.

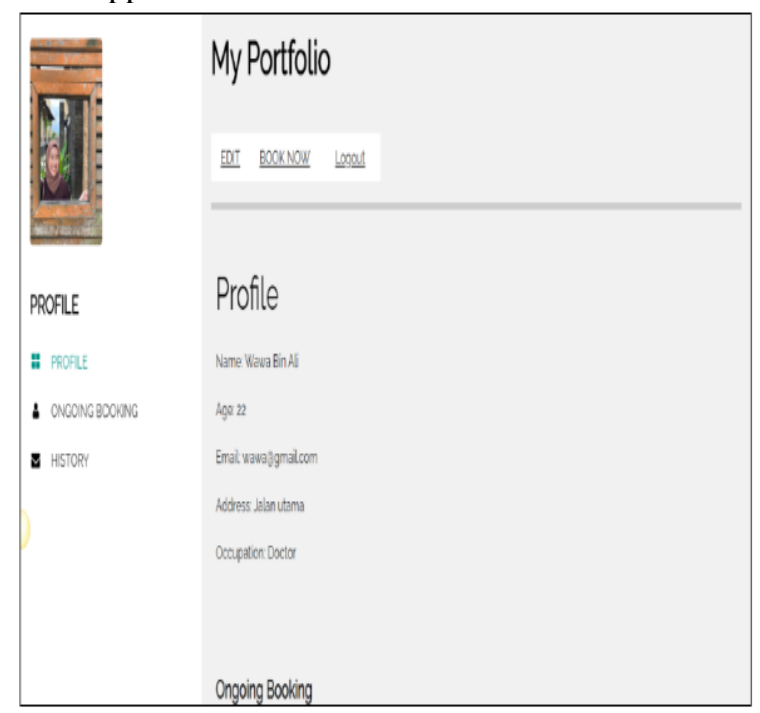

Figure 2: Local Community Profile Who Acquires Services

In this feature, local community who requires home helper services may update detailed information of himself so that it becomes visible to others especially to the administrator of the i-HomeHelper and home helpers. The history or ongoing booking of services that had been done are also recorded and displayed here. Next, in Figure 3, profile of the home helper who offers service can be viewed andedited (by the owner of the profile only). Local community users can carry out their own checks and references in order to find the best fit for their intended purposes. 


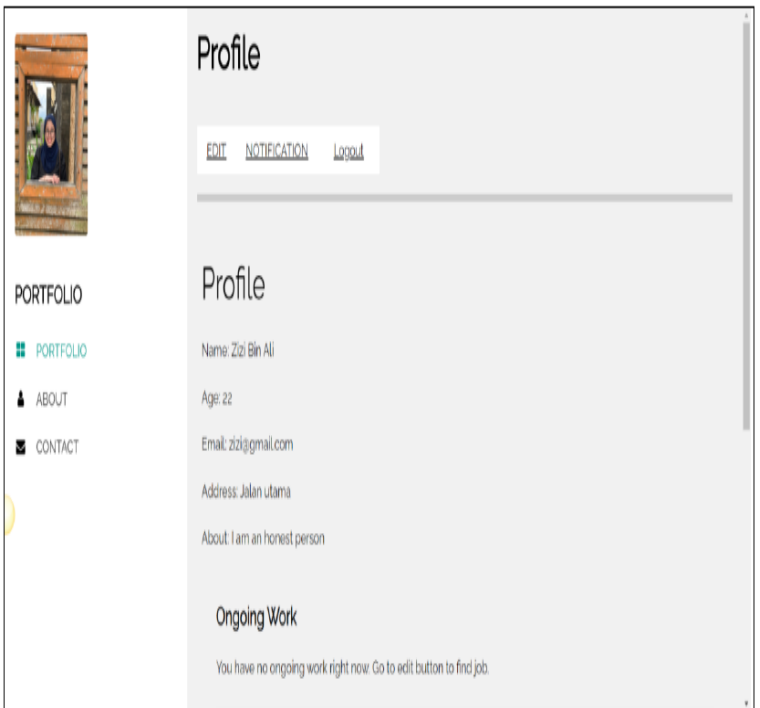

Figure 3: Profile of the Home Helper

Figure 4 represents the interface for the booking arrangement where the local community users can proceed with the booking process. In this feature, available home helpers are displayed based on the best fit that match the location proximity, services offered/acquired and/or rate on service charges. Local community users can also refer to the rating given by others in order to get second opinions, references or feedback on the home helper services given.

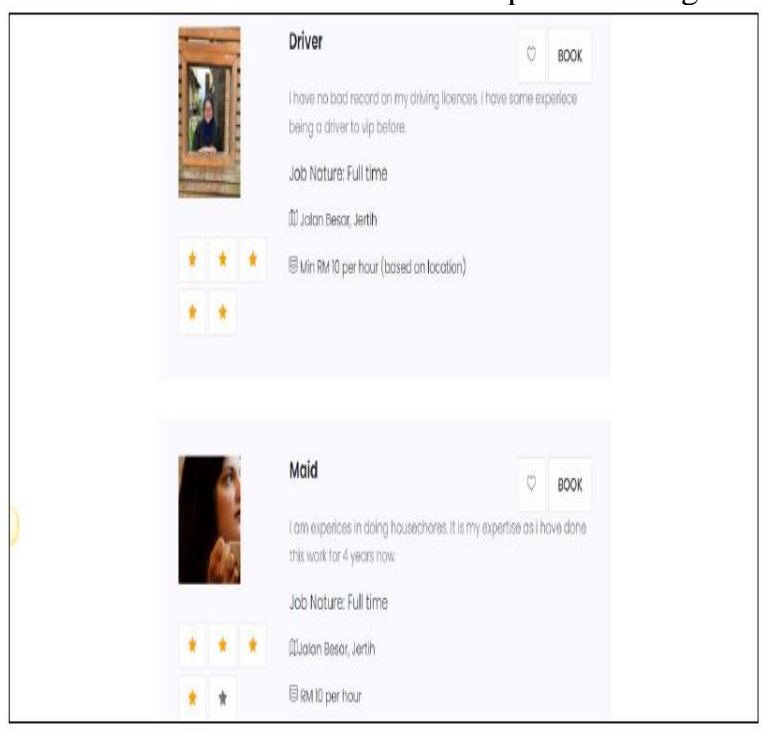

Figure 4: Available Home Helper Services

The local community users can look for nearby services available as shown in Figure 5.

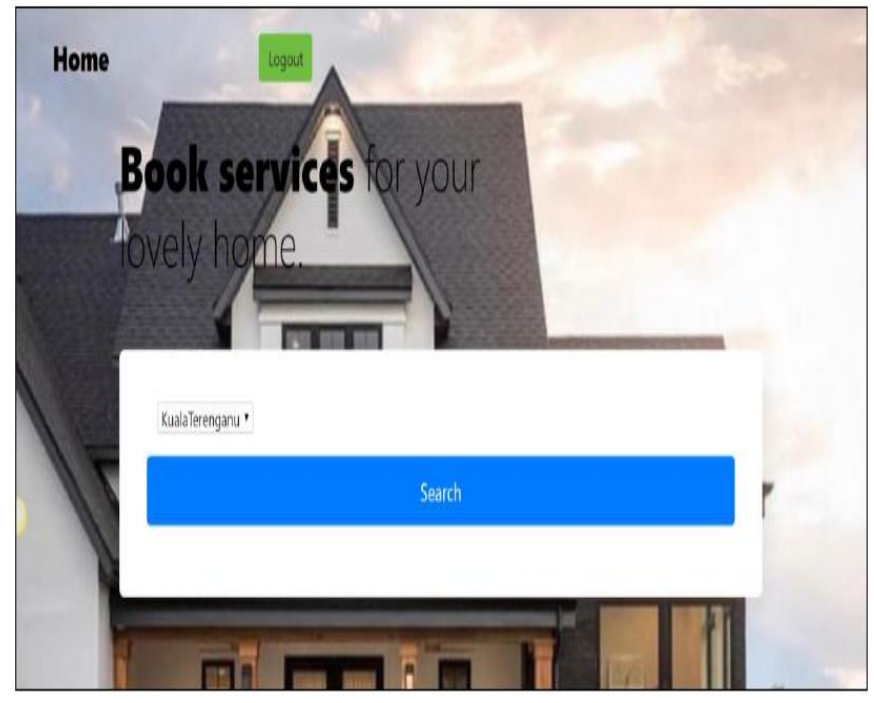

Figure 5: Book for Available Services

\section{Conclusions And Future Works}

i-HomeHelper was developed as one stop information centre for whom requires information pertaining to house helper and services. Also, at the same time it becomes as the platform for house helpers to be listed into the system. The system will cater various needs and reasons of an employer to-be and fulfil the search for suitable helpers. This study provides a platform to connect and bridge the gap between these two groups of people. i-HomeHelper may bring people together by building an online local community based on trust and support. In the near future, two new features will be added that are service notification requested and accepted and special request for home helper services that are shariah compliance.

\section{References}

[1] Usher, and. (2009). General specialists comprehend the segments of unwavering quality, intelligence and convenience related with wellbeing destinations. Conduct and Information Technology, 28 (1), 39-44.

[2] Shahzool Hazimin Azizam, Syarilla Iryani Ahmad Saany, Eimir Azli Md Noh., Nik Azman Nik Hashim, Muhammad Waqas, Yousef A. Baker El-Ebiary, Blockchain as A Secure and Decentralized Communication Tool for Future Sustainable Development- Palarch's Journal of Archaeology of Egypt/Egyptology 17(9) (2020) p. 942953.

[3] Yousef A.Baker El-Ebiary, Samer Bamansoor, Waheeb Abu-Ulbeh, Wan 
Mohd Amir, Syarilla Iryani A. Saany, M. Hafiz Yusoff. "Using Interval Manager Mobile Application in Saving Time and Cost” Vol. 68, Editor's Issues, Oct. 2020, pp. 82-85, IJETT, Doi: 10.14445/22315381/CATI1P214.

[4] Syarilla Iryani A. Saany, Elsayed M. S. S. Elawadi, Yasser M. Tarshany, M. Hafiz Yusoff, Yousef A.Baker El-Ebiary, Nur Hikmah Binti Ismail. (2020). Utilizing the AR and Mobile Apps to Show the Rhetorical Miracle of the Fetal Growth Stages According Quran. IJFGCN, 13(3), 1068-1081.

[5] Alol, and. S., Liu, M.S., Al-Zawawi, N. Industry Revolution IR 4.0: Future Opportunities and Challenges in the Construction Industry. In the MATEC Conference Network (Vol. 203, p. 02010). EDP Science.

[6] Wang, H. G., \& Detterich, B. C. (2009). U.S. Patent No. 7,579,984. Washington, DC: U.S. Patent and Trademark Office.

[7] (3) Jiao, Y., Rino, C., and Morton, Y. T. (2018). Reproduced ionospheric streak on central GPS signs of dynamic stages. Route: Journal of the Institute of Navigation, 65 (2), 263-274.

[8] Vander Velde, W., Cafarella, J., Tseng, H. W., Dimos, G., \& Upadhyay, T. (2011). U.S. Patent No. 7,994,971. Washington, DC: U.S. Patent and Trademark Office.

[9] Lodza Ngbagaro.P. (2016,October 20). Title: System Development Methodologies.

[10] Vijay. (2019,November 10).Title: SDLC Methodologies, Phases, Process and Models

[11] Azrul Azmi.(2015).Maideasy app(4.6.3) [Mobile Application Software].

[12] Rajiv.R.Pandey.(2017)HelpersNearMe app (2.0.31)[Mobile Application].

[13] Meenakshi Gupta Jain.(2014).Helper4U (3.0)[Web Based software].

[14] Abhiraj.Bal.(2014).UrbanClap Beauty and Home
Services app (7.1.42) [Mobile Application]. 